the proportion of urine had fallen to eight scruples; and on the 10th, that fluid was completely healthy.

In reference to the foregoing cases, $M$. Bouchardat observes, that the only difference in treatment between the two successful and two unsuccessful ones, was the use of the flannel clothing in the former. The skin was excited to constant diaphoresis,* and the carbonate of ammonia did not pass off by the urine, which remained constantly acid.

\section{ASSURANCE OFFICE FEES.}

TO THE FDITORS OF THE PROVINCIAL MEDICAL ANI SURGICAL JOURNAL.

Gentremen, - If you consider the following statement and correspondence, relative to insurance offices, worthy of your pages, I shall feel obliged by your giving them an early insertion.

Your obedient servant, George Harver.

Castle Hedingham, Essex, Nov. 22, 1811 .

On the 16th November I received one of the usual letters, containing seventeen queries from the secretary of the "Clergy Mutual Assurance Society," but without either a fee inciosed, or any intimation that one would be forthcoming, I, therefore, immediately sen the following letter:-

\section{"Castle Hedingham, "Nov. 16, 1841 .}

"Sir,-In reply to your letter of yesterday, containing various questions relative to the health of the Rev. , I beg leave to inform you that I have, in common with many other surgeons, formed the resolution of not replying to such queries without a fee; which fee we have no hesitation in saying ought to be paid by the proprietors of the office, as they (and not the individual desirous of insuring) ask the questions for their own safety and satisfaction. If, therefore, you will have the goodness to forward me the sum of one guinea, all the questions shall be immediately and decidedly answered.

$$
\text { "I am, Sir, }
$$

"Your obedient servant, "G. Harvey."

"To William Webb Esq."

By return of post I received the following answer:" 40, Parliament-street, "Nov. 17, 1841 .

"Sir,-In the "Clergy Mutual Assurance Society" there is neither a proprictary, or any paid directors; the latter render their services gratuitously for the benefit of the profession; and as, therefore, the assured members alone share the whole of the profits, the society does not undertake the payment of medical fees.

"I have inclosed your note to the Rev. "I am, Sir,

$$
\text { "Your obedient servant, }
$$

"W. WEBB."

\section{"To G. Harvey, Esq."}

The same post also brought me the following letter from my friend, who was desirous of insuring :-

"Nov. 18, 1841.

"Sir,-I have this morning received from the "Clergy Mutual Assurance Office" your note addressed thereto respecting the fee. The secretary writes

- As an illustration of the benefit to be derived from storing the functious of the skin in cases of diabetes, we may mention that our friend, Dr. Imray, of Manchester, has informed us that he knew several patients afflicted with this disease, who recovered on removing to a warm climate. EDB.] me word that, as there is neither a proprietary or any paid directors, the assured members alone share the whole profits, and that, under these circumstances, the society does not undertake the payment of medical fees.

"It appears strange to me that all usual and neces. sary expences are not paid by the office, and deducted from the profits. As it appears not to be their practice, I shall be happy to bear the fee myself.

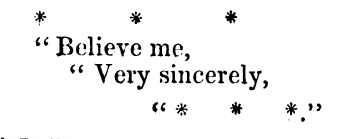

I immediately sent the following letter to the office :-

$$
\begin{aligned}
& \text { "Castle Hedingham, } \\
& \text { "Nov. 19, } 1841 \text {. }
\end{aligned}
$$

"Sir,-In reply to yours of the 17 th, stating that there is neither a proprietary, or any paid directors, in the "Clergy Mutual Assurance Society," and that the dirccturs render their services gratuitously for the benefit of the profession, I beg leave to observe, that if your society, or any other association of gentlemen, resolve to render their services gratuitously for their own mutual bonefit, they are undoubtedly at liberty so to do: but I camnot understand that such resolution gives them any claim to the gratuitous services of the medical profession, in order to enable them to decide on the eligibility, or otherwise, of those desiring to insure at their office.

"I am greatly obliged to your enclosing my letter to the Rev. - - as it it has enabled him to view the matter in what I consider its proper light: he agrees with me in opinion that the fee ought to be paid by the office, and deducted from the profits; but, as this is not your practice, offers to pay it himself. This, I hope, on reconsidering the matter, you will not allow him to do.

"I have returned your letter, with all the questions answered in what I hope will prove a satisfactory manuer to all parties; and remain, Sir,

$$
\text { "Your obedient servant, }
$$

\section{"To Wm. Webb, Esq.",}

"G. Harvey."

Here the matter rests for the present. I have heard nothing more from the office, nor do I suppose I shall till they again require my professional opinion; but I am firmly resolved, neither they, nor any other assurance office, shall have any medical opinion from me without the fee of one guinea; and I earnestly request all my professional brethren to form the same resolution; and in order to induce them firmly to insist on their demand, I will take the liberty of relating a little anecdote.

Some few years since I received one of the usual letters from the National Provident Institution, which I refused to answer without a fee : one of their agents waited upon me, and informed me he had already given a fee to a medical gentleman employed by the office, and that no other opinion would be paid for I advised him to rest satisfied with the opinion he had gained. "No," he replied ; " the surgeon employed by the office has never attended this person professionally, and scarcely knows him; but you are his medical adviser, and have known him for several years, therefore I must have your answers to these questions." I told him positively I would not answer a single question without a fee; he then said he would consult the Directors, and left me. A short time afterwards he called again and offered me half a sovereign; this I refused, telling him I was neither a Jew nor a horse-dealer; when, after saying I was the most obstinate man he had ever met with, down came the guinea!

G. H. 